\title{
自由地下水面をもつ半無限領域内の \\ 円形暗きょの取水量について \\ UNCONFINED FLOW INTO INFILTRATION GALLERIES \\ IN SEMI-INFINITE HOMOGENEOUS SOIL
}

\section{1.まえがき}

自由地下水面をもつ, 均一な透水性の半無限浸透領域 に, 円形の集水暗きょを埋設して, 地下水を取水する場 合を考える。暗きょによる取水開始前に, 水平な直線で あった自由地下水面は, 取水を行ならことによって, 暗 きょ付近が局部的に低下した曲線になる。この自由地下 水面は, 毛管上昇帯を通る流れを無視すれば, 最も上側 の流線であり，自由地下水面より下の部分が暗きょに対 する浸透領域である。したがってこの場合には, 地表面 上に湛水がある場合 ${ }^{1), 2)}$ とは異なり, 暗きょ取水量だけ でなく, 浸透領域の形そのものが解析の対象になる。

これまでの研究として, 暗きょ内水位が暗きょ中心と 一致している場合の Hooghoudt による近似解, あるい は暗きょがちょうど満流していて,さらに暗きょ頂部に 自由地下水面が達している場合の Van deemter による 厳密解などがあるが3),4), これらは暗きょ内水圧が特定 の場合の解であり, 暗きょ内水圧が任意の值の場合には 適用できなかった。

本論文は, 半無限浸透領域内に暗きょが 1 個埋設され た場合上, 同じ深さの位置に, 同規模の暗きょが多数並 列された場合とについて, 暗きょ内が満水状態と末満水 状態における解を複素ポテンシャル理論により導いた。 この結果より, 満水状態では種々の暗きょ内水圧の場 合, および末満水状態では種々の暗きょ内水位の場合の 暗きょ取水量と自由地下水面の形状などを求め, これを 粘性流体を用いた Hele-Shaw モデル実験によって検証 した。

\section{2. 基礎 式}

図一1 に示すような流れの場の, 任意点 $(x, y)$ にお $*$ 正会員 九州大学助手 工学部水工士木学科

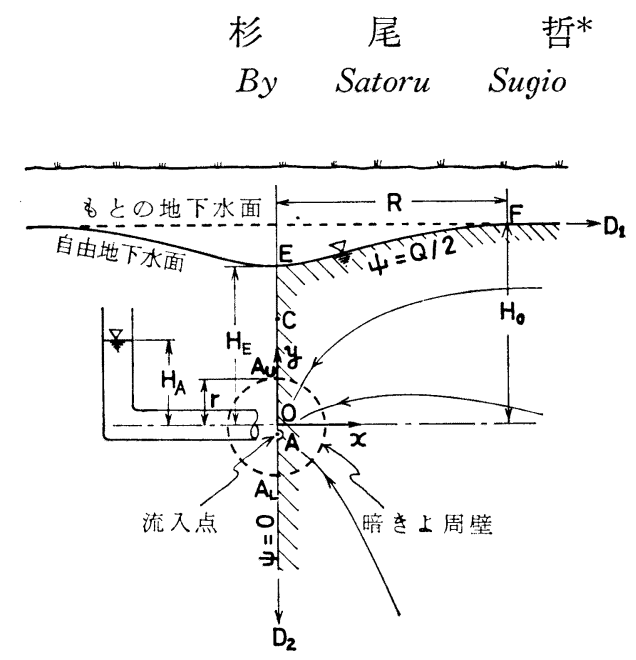

図一1 暗きょが 1 個の場合の $z$ 平面

ける速度ポテンシャルのは, その点の圧力を $p$, 透水倸 数を $k$, 水の単位体積重量を $w$ とすると,

$$
\Phi=k\{(p \mid w)+y\} \text {. }
$$

で表わされる。いま図一1の自由地下水面の速度ポテン シャルを求めると， $p=p_{a}$ (大気圧) $=0$ より, $\Phi=k y$ となる。したがって $\theta_{1}=\emptyset-k y$ で表わされる Zhukovsky 関数 ${ }^{5}$ を用いると, $z$ 平面で曲線をなす自由地下水面 が, $\theta$ 平面では $\theta_{1}=0$ の直線で表わされることになる。 また $\theta_{1}$ の共役関数として, 流れ関数 をを用いて $\theta_{2}=\psi$ $+k x$ と打くと, $\theta_{1}$ と $\theta_{2}$ は直交条件を満足し, ともに Laplace の式を満足する。ここに

$$
\begin{aligned}
& W=\Phi+i \psi, z=x+i y \text { より } \\
& \Theta=\Theta_{1}+i \Theta_{2}=W+i k z \cdots \cdots
\end{aligned}
$$

\section{3. 暗きょが 1 個の場合の解析}

半無限浸透領域に, 円形の集水暗きょを 1 個埋設して 取水する場合の, 暗きょ取水量と自由地下水面の形状を 検討してみよう。

\section{（1）複素ポテンシャル}

いま，暗きょ内に流入点を仮想して，暗きょへ向う流 
れを流入点へ向う流れにおきかえ，このポテンシャル流 の解を用いて暗きょへの流れを解析することにしょう。 まず $z$ 平面の座標軸の原点を暗きょの中心点に選び, 流 入点を $\mathrm{A}$ 点とし, 流入点への流入量を $Q^{\prime}$ とおいて, 式 （2）上り領域境界上の $\Theta$ の值を求めると， $\mathrm{D}_{1} \mathrm{FE}$ 区間 で $\theta_{1}=0, \mathrm{EA}$ 区間で $\theta_{2}=Q^{\prime} / 2, \mathrm{AD}_{2}$ 区間で $\theta_{2}=0$ とな

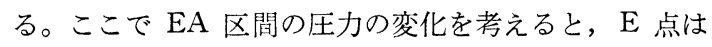
淀み点であり, $\mathrm{E}$ 点の近傍では流速が小さいから, $\mathrm{E}$ 点 より下のある範囲は, 下にゆくにつれて圧力が静水圧分 布的に大きくなってゆくと考えられる。また $\mathrm{A}$ 点は流入 点であるから $p=-\infty$ である。したがって $\mathrm{EA}$ 区間の $\Theta_{1}$ の值は, $\mathrm{E}$ 点付近では下にゆくにつれ増加し, EA 区 間の途中で最大值を示した後減少し, $\mathrm{A}$ 点で $\theta_{1}=-\infty$ となるものと考元れれ る。この $\boldsymbol{\theta}_{1}$ が最大に なる点を $\mathrm{C}$ 点とする と, 図一1 のハッチの 部分が図一2 のように かける。次に図一2を 図一3 $㇒ t$ 平面の上半 面に写像するとき, D 点を無限遠点に, $\mathrm{E}$ 点 $\mathrm{D}_{1} \frac{\mathrm{F}}{\mathrm{F}} \mathrm{C} \mathrm{A} \rightarrow \mathrm{D}_{2}$ を $t=0$ に, $\mathrm{A}$ 点を $t$ 図-3 $t$ 平面 $=1$ に選び, $\mathrm{C}$ 点の位置を $t=m^{2}$, 係数を $M$ とおく と, 写像関数は Schwarz-Christoffel の変換式より

$$
\Theta=M \int \frac{t-m^{2}}{\sqrt{t} \cdot(t-1)} d t \cdot \cdots
$$

となる。さらに

$$
\sqrt{t}=\zeta i
$$

と扔くと, 式 (3) は積分定数を $C_{1}$ とするとき,

$$
\theta=2 M i\left[\zeta-\left(1-m^{2}\right) \cdot \tan ^{-1} \zeta\right]+C_{1} \cdot \cdots
$$

となり,式 (4) の変換により, 図一 3 の実軸上の半平面は 図一4の 4 半平面に写像される。また同様にして, 図一 1 の左半分の領域は, 図一4 のハッチの部分 の左隣に写像されるか ら, 図一1 の流入点一 の流れが, 図-4 の流 入点への流れに写像さ れることになる。この 図一4 の流入点への流 れは, $\xi$ 軸汇関してA 点と対称な位置 $\mathrm{A}^{\prime}$ 点 に, $\mathrm{A}$ 点と同じ強さの 流入点を仮想した，無 限領域に流入点が $2 つ$ ある場合のポテンシャ

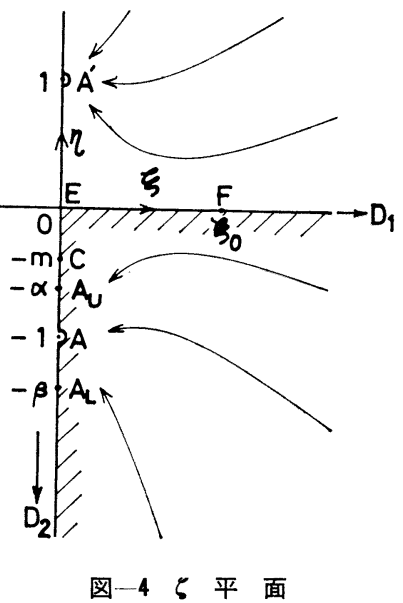

ル流と同じであり，1つの流入点への流入量を $Q^{\prime}$ とお くと, 複素ポテンシャルは次式で与えられる。 $W=\left(Q^{\prime} / 2 \pi\right) \cdot \ln (\zeta+i)(\zeta-i)+\mu \cdots \cdots \cdots \cdots \cdot(6)$ したがって，式（6）を式（2）（5）と連立させれば， $\zeta$ 平面および $\theta$ 平面を媒介平面として, $z$ 平面と $W$ 平面 の対応がつくから, 図一1 の流入点への流れを解くこと ができる。

\section{（2）末知定数の決定}

式 (5)に $\zeta=\xi+i \eta$ を代入して実数部と虚数部にわ けると，

$$
\begin{aligned}
& \Theta_{1}=-2 M\left(\eta-I_{m}\right)+C_{1} \\
& \Theta_{2}=2 M\left(\xi-R_{e}\right) \cdots \cdots \cdots
\end{aligned}
$$

ここに

$$
\begin{aligned}
& R_{e}=-\left(1-m^{2}\right) / 2 \cdot \tan ^{-1}\left\{2 \xi /\left(\xi^{2}+\eta^{2}-1\right)\right\} \cdots(9) \\
& I_{m}=\left(1-m^{2}\right) / 4 \cdot \ln \left[\left\{\xi^{2}+(\eta+1)^{2}\right\} /\left\{\xi^{2}+\left(r_{i}-1\right)^{2}\right\}\right]
\end{aligned}
$$

ここで式 (9) の逆正接の值を, $\mathrm{AD}_{2}$ 線上で $0, \mathrm{EA}$ 線 上で $\pi$ と選ぶと, $\mathrm{EA}$ 線上では $\Theta_{2}=Q^{\prime} / 2$ であるから， 式 (8) より $M_{1}=Q^{\prime} \mid\left\{2 \pi\left(1-m^{2}\right)\right\}$ をうる。また $\mathrm{E}$ 点 $(\xi=\eta=0)$ では $\theta_{1}=0$ であるから, 式 (7) より $C_{1}=0$ となる。以上の值を式 (7)，（8）に代入して整理する と,

$$
\begin{gathered}
\Phi-k y=-\frac{Q^{\prime} \eta}{\pi\left(1-m^{2}\right)}+\frac{Q^{\prime}}{4 \pi} \cdot \ln \frac{\xi^{2}+\cdot(\eta+1)^{2}}{\xi^{2}+(\eta-1)^{2}} \\
\cdots \cdots \cdots \cdots \cdots \cdots \cdots \cdots \cdots \cdots \cdots \cdots \cdots \cdots \cdots \cdots \cdots \cdots \cdots \cdots \cdots \cdots \cdots \\
\psi^{\prime}+k x=\frac{Q^{\prime} \xi}{\pi\left(1-m^{2}\right)}+\frac{Q^{\prime}}{2 \pi} \cdot \tan ^{-1} \frac{2 \xi}{\xi^{2}+\eta^{2}-1}
\end{gathered}
$$

がえられる。

次式 (6) を実数部と虚数部にわけると,

$$
\Phi=\left(Q^{\prime} / 4 \pi\right) \cdot \ln \left\{\xi^{2}+(\eta-1)^{2}\right\}\left\{\xi^{2}+(\eta+1)^{2}\right\}+\mu
$$

$$
\psi=\left(Q^{\prime} / 2 \pi\right) \cdot \tan ^{-1}\left\{2 \xi \eta /\left(\xi^{2}-\eta^{2}+1\right)\right\}
$$

となる。ここで $\mathrm{E}$ 点の $の$ の值を求めると, 式 (13) 上 り $\Phi=\mu$ となり, $\mathrm{E}$ 点の自由地下水面の高さを $H_{E}$ と おくと, 式 (1) より $\Phi=k H_{E}$ となるから， $\mu=k H_{E}$ で ある。

\section{(3) 流入点への流入量 $\boldsymbol{Q}^{\prime}$}

式 (11)～(14) に各点の境界条件を与えて, 流入点一 の流入量の算定式を導いてみよう。

地下水位回復位置 $\mathrm{F}$ 点に扔いては, $\Phi=k H_{0}, x=R$, $\psi=Q^{\prime} / 2, \eta=0$ であるから, $\xi=\xi_{0}$ とおくと, 式 (12), (13)より

$$
\begin{aligned}
& \frac{2 \xi}{1-m^{2}}+\tan ^{-1} \frac{2 \xi_{0}}{\xi_{0}^{2}-1}=\frac{2 \pi k}{Q^{\prime}} R+\pi . \\
& Q^{\prime} /(2 \pi k)=\left(H_{0}-H_{E}\right) / \ln \left(\xi_{0}^{2}+1\right) .
\end{aligned}
$$


暗きょ周壁の下端 $A_{\mathrm{L}}$ 点においては, $\Phi=k H_{A}, y=$ $-r, \xi=0$ であるから, $\eta=-\beta(\beta>1)$ とおくと, 式 (11), (13)より

$$
\begin{aligned}
& \frac{2 \beta}{1-m^{2}}+\ln \frac{\beta-1}{\beta+1}=\frac{2 \pi k}{Q^{\prime}}\left(H_{A}+r\right) \\
& H_{E}=H_{A}-Q^{\prime} /(2 \pi k) \cdot \ln \left(\beta^{2}-1\right) \cdots
\end{aligned}
$$

暗きょ周壁の上端 $\mathrm{A}_{\mathrm{U}}$ 点においては, 暗きょ内が満水 状態と末満水状態とで境界条件が異なるから，それぞれ 別個に考える。

まず暗きょ内が満水状態の場合, $\Phi=k H_{A}, y=r, \xi=$ 0 であるから, $\eta=-\alpha(\alpha<1)$ とおくと, 式 (11) より

$$
\frac{2 \alpha}{1-m^{2}}+\ln \frac{1-\alpha}{1+\alpha}=\frac{2 \pi k}{Q^{\prime}}\left(H_{A}-r\right)
$$

式 (13) より

$$
H_{E}=H_{A}-Q^{\prime} /(2 \pi k) \cdot \ln \left(1-\alpha^{2}\right)
$$

となるから, 式 (18) と連立させれば

$$
\beta^{2}=2-\alpha^{2}
$$

がえられる。したがって，暗きょ内が満水状態の場合の 流入点への流入量 $Q^{\prime}$ と地下水面の最低点の高さ $H_{E}$ は 式 (15)，(16)，(17)，(18)，(19)，(20）を連立させ て, 与えられた境界 $H_{A}, r, H_{0}, R$ について解いてえら れる。

次に暗きょ内が未満 水状態の場合には，図 一5(a)のように, 暗き よ周壁の上端は自由地 下水面より上にあっ て，浸透領域の外にな

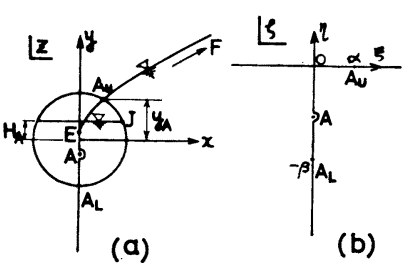
るため, この点に相当 図一5 暗きょ内が末㴖水状態の場合 する $\zeta$ 平面の位置は存在しない。そこで暗きょ周壁と自 由地下水面との交点を $\mathrm{A}_{\mathrm{U}}$ 点と考える。この $\mathrm{A}_{\mathrm{U}}$ 点の 位置は末知であり, いま $y=y_{A}, \xi=\alpha(\alpha \geqq 0)$ とおく と, $\Phi=k y_{A}, \psi=Q^{\prime} / 2, x=\sqrt{r^{2}-y_{A}{ }^{2}}, \eta=0$ であるから 式 (12), (13) より

$$
\begin{aligned}
& \frac{2 \alpha}{1-m^{2}}+\tan ^{-1} \frac{2 \alpha}{\alpha^{2}-1}=\frac{2 \pi k}{Q^{\prime}} \sqrt{r^{2}-y_{A}^{2}}+\pi \\
& y_{A}=Q^{\prime} /(2 \pi k) \cdot \ln \left(\alpha^{2}+1\right)+H_{E}
\end{aligned}
$$

がえられる。したがって暗きょ内が未満水状態の場合の 流入点への流入量 $Q^{\prime}$ などは, 式 (15), (16), (17), (18)，(21)，（22）より求めることになるが，末知数と して $y_{A}$ が 1 個増えたために, 一般には解は求まらな い。しかし, 自由地下水面が図一5(a) の $\mathrm{J}$ 点を通る場 合には, $\mathrm{A}_{\mathrm{U}}$ 点の位置が $y_{A}=H_{A}$ と既知であるから, 満水状態と同様にして，解を求めることができる。この $y_{A}=H_{A}$ の場合の解を種々求めて検討してみると, 境界 条件として与えた $R$ の值が小さいほど，算定式の解の $m^{2}$ の值は小さくなり, ある值 $R=R_{0}$ のとき $m^{2}=0$ と
なる。ここに C 点の位置は, その定義より考えて, $m^{2}$ $\geqq 0$ であるから，境界条件が $R<R_{0}$ の場合には， $y_{A}>$ $H_{A}$ でなければならない。そこで本論文では， $y_{A}$ が最 小の場合の解を次の方法により求め, これを暗きょ内が 末満水の場合の近似解とした。まず式(15), (16), (17), (18)，(21)，(22) に $R$ 以外の境界条件を与えて $m^{2}=$ $0, y_{A}=H_{A}$ について解き, $R_{0}$ の值を求める。ついで境 界条件として与えた $R$ の值が $R<R_{0}$ であれば $m^{2}=0$ とおき，R>R $R_{0}$ であれば $y_{A}=H_{A}$ とおいて，再び式 (15)，(16)，(17)，(18)，(21)，(22）を解くと, 暗き ょ内が未満水状態での流入点への流入量 $Q^{\prime}$ と, 暗きょ 周壁での自由地下水面の高さ $y_{A}$ および $H_{E}$ (この場合 には物理的な意味はない) が求まる。

なお暗きょ内が未満水状態で, 自由地下水面が暗きょ の位置まで下がらず， $\dot{H}_{E}>r$ となる場合が考えられる が，この場合の解は $R$ の值が非常に小さい場合にしか 存在しないので, 本報では検討していない。

\section{（4） 暗きょ取水量 $\boldsymbol{Q}$}

以上の解析によってえられた流入点への流入量 $Q^{\prime}$ が，暗きょ周壁への流入量すなわち暗きょ取水量 $Q$ と， どの程度一致しているか調べてみよう。まず式 (1)より 暗きょ周壁上のポテンシャル分布を調べてみると，暗き ょ内が満水状態の場合には, 暗きょ周壁全体が $\Phi=k H_{A}$ の等ポテンシャル線であり, 未満水状態の場合には, 暗 きょ内水面より下の部分で $\Phi=k H_{A}$ の等ポテンシャル 線である。いま $r / H_{0}=0.2, R / H_{0}=10.0$ の場合につい て, 式 (11) （14）を用いて流入点のまわりの $\Phi=k H_{A}$ の等ポテンシャル線を求めてみると, 図一6 の点線のよ らになり，いずれも暗 きょ周壁より収縮した 曲線になっている。し たがって，流入点への ポテンシャル流の各流 線上では，図一6 の点 線が暗きょ周壁より収

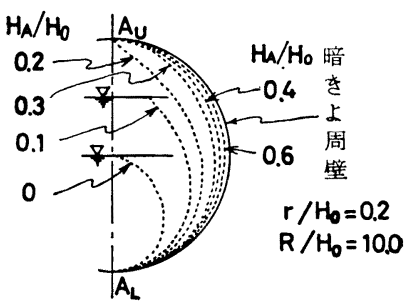
縮している分だけ，実 図一 $\boldsymbol{\theta} \Phi=\boldsymbol{k} \boldsymbol{H}_{A}$ の等ポテンシャル線 際の暗きょ周壁に対するポテンシャル勾配より小さな勾 配で流れていることになり, 流入点への流入量はその分 だけ暗きょ取水量より小さな值を示すことになる。そこ で流入点へのポテンシャル流の各流線上において, 暗き ょ周壁の位置で, 与えられた暗きょ周壁の速度ポテンシ ヤルに一致するよらに補正した場合の流入点への流入量 を求めてみよら2)。

まず流入点へのポテンシャル流において, 暗きょ周壁 上の任意点 $\mathrm{P}$ の速度ポテンシャルを $\Phi=k H_{1}$ とし， $=k H_{0}$ の位置から $\mathrm{P}$ 点までの流線の長さを $l$ とすれ 
ば， $\mathrm{P}$ 点における円周方向の単位長さ当りの流入量 $q_{1}$ は, Darcy 式より

$$
q_{1}=C_{0} k\left(H_{0}-H_{1}\right) / l=d \psi / r d \theta
$$

ここに, $C_{0}$ は係数, $\psi$ は $\mathrm{P}$ 点の流れ関数, $\theta$ は暗き ょ中心 $\mathrm{O}$ と $\mathrm{P}$ 点を結ぶ直線が，直線 $\mathrm{OA}_{\mathrm{L}}$ となす角と する。

次に実際の暗きょへの流れにおいて，P点の速度ポテ ンシャルを $\Phi=k H_{t}$ とすると, 実際の暗きょ周壁での 単位長さ当りの流入量 $q_{t}$ は

$$
q_{t}=C_{0} k\left(H_{0}-H_{t}\right) / l
$$

ここに, 暗きょ内が満水状態の場合 $H_{t}=H_{A}$, 未満水状 態の場合は, $\mathrm{P}$ 点が暗きょ内水面より下のとき $H_{t}=$ $H_{A}$, 内水面より上のとき $H_{t}=y=-r \cdot \cos \theta$

以上の $q_{1}, q_{t}$ より $C_{0}$ を消去すれば

$$
q_{t}=\frac{d \psi}{r d \theta} \frac{H_{0}-H_{t}}{H_{0}-H_{1}}
$$

となり，暗きょ周壁の全体からの流入量 $Q$ は， $q_{t}$ を円 周 $s$ に沿って積分してえられる。

$$
Q=2 \int_{A_{U}}^{A_{L}} q_{t} \cdot d s=2 \int_{0}^{\theta_{m}} \frac{d \psi}{r d \theta} \frac{H_{0}-H_{t}}{H_{0}-H_{1}} \cdot r d \theta
$$

ここに, 暗きょ内が満水状態のとき, $\theta_{m}=\pi$, 未満水状 態のとき

$$
\theta_{m}=\sin ^{-1}\left(y_{A} / r\right)
$$

この流入量 $Q$ を, 求める暗きょ取水量と考える。式 (23) の積分を行なうとき, 式中の $\psi, H_{1}$ の值は, 式 (15) ～(22) よりえられる流入点への流入量 $Q^{\prime}$ を用いて， 式 (11) （14）より算出できるが, 式 (11) (14) が $\xi$, 》索媒介変数として表わされているため, 式 (23) の解 析的な解をらることはできない。したがって数值積分に より求めることにする。すなわち, 暗きょ周壁上の各点 の 分の各分点における $d \psi / r d \theta$ の值を数值微分によって 求め, これに各分点の $r\left(H_{0}-\dot{H}_{1}\right) /\left(H_{0}-H_{t}\right)$ の值を乗 じたものを各分点の值として数值積分を行なえば，暗き 上取水量 $Q$ が求まる。

\section{（5）自由地下水面と流線網}

自由地下水面は式 (2) の Zhukovsky 関数によって， ら平面の $\xi$ 軸上に写像されており, 毛管上昇帯での浸透 を考えなければ，浸透領域の最上部の流線が自由地下水 面であるから，式 (11)〜(13) に $\eta=0, \psi=Q^{\prime} / 2$ を代 入すると, 次式のような自由地下水面の方程式がえられ る。

$$
\begin{aligned}
& x=\frac{Q^{\prime}}{2 \pi k}\left(\frac{2 \xi}{1-m^{2}}+\tan ^{-1} \frac{2 \xi}{\xi^{2}-1}-\pi\right) \\
& y=\frac{Q^{\prime}}{2 \pi k} \cdot \ln \left(\xi^{2}+1\right)+H_{E} \cdots \cdots \cdots \cdots \cdots
\end{aligned}
$$

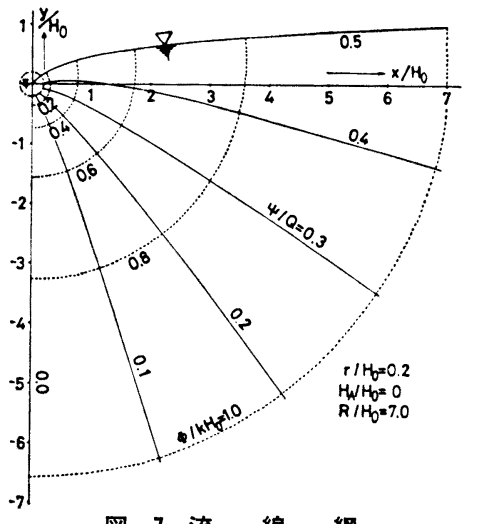

図一7流線網

したがって, 流入点への流入量の算定式より求めた $\left(Q^{\prime}\right.$, $H_{E}$ および $m$ の值を上式に代入すれば， $\xi$ を媒介変数 として自由地下水面が描かれる。また $Q^{\prime}, H_{E}, m$ の值 を式 (11) （14）に代入すれば, 領域内部の $\Phi ， \psi の$ 值 が $\xi ＼eta \eta$ を媒介として求まるから，これより図一7のよ うな流線網が描かれる。こ図一7 は $H_{A} / H_{0}=0, r / H_{0}$ $=0.2, R / H_{0}=7.0$ の場合について求めたものである。 なお以上の自由地下水面および流線網は, 流入点へのポ テンシャル流の解であるから，実際の形とは若干異なる ことが考えられる。

\section{4. モデル実験による検証}

\section{（1） Hele-Shaw モデル実験}

以上の解析結果の検証実験として, Hele-Shaw デル を用いた実験を行なった。このモデル実験は，非常に狭 い間隔の 2 枚の平行平板間を粘性流体がゆるやかに流れ るとき，この流れが浸透流と同じ Laplace 式を満足す ることを利用したもので6)，主として自由地下水面を有 する流れの場合に用いられる。一般に砂モデルで自由地 下水面形を求める場合には，色素等を流しても，毛管浸 透のために不鮮明になってしまうので，多数の点の圧力 を測定して，圧力が大気圧と等しくなる位置を推定し， これを自由地下水面の位置とする方法が用いられる7゙。 しかし，この方法も地下水面の勾配が大きくなると，か なりの測定誤差を生ずる。この点 Hele-Shaw モデルの 場合には直視観測できるので誤差も少なく，しかも実験 装置およびその操作が簡単であるから，自由地下水面の 形状 ${ }^{8)}$ あるいは地下密度流の境界面の形状9)などの検討 に利用されているようである。なおモデルの透水係数 は, 平板間隔を $D$, 動粘性係数を $\nu$, 重力の加速度を $g$ とすると，平板間の平均流速の式と Darcy 式との相似 関係から，次式で表わされる。

$$
k=g D^{2} /(12 \nu)
$$




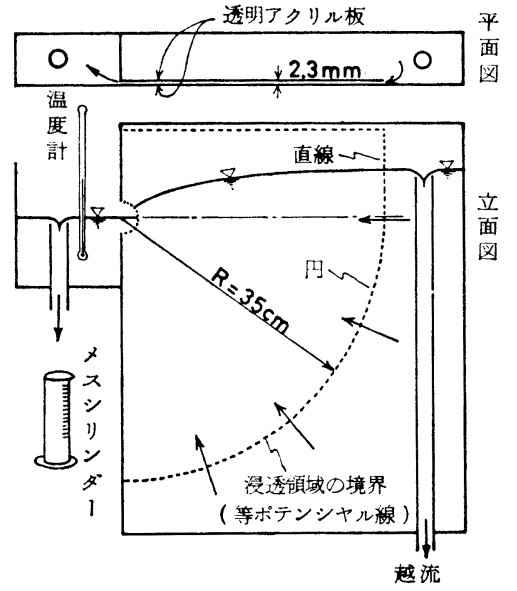

図一8 実験装置の概略図

本研究に用いた実験装置は, 図一8 の平面図に示すよ うに，2枚の透明のアクリル板（厚さ $5 \mathrm{~mm}$ ）を用いた もので, 内側の板を立面図の点線のような形に切って, 外側の板との間を浸透領域とした。この点線の形は図一 7 を参考にして, 暗きょ中心点を中心とする $R=35 \mathrm{~cm}$ の円と直線で近似した。また平板の間隔は $2.3 \mathrm{~mm}$ で あった。粘性流体には温度 $20^{\circ} \mathrm{C}$ で $\nu=0.83 \mathrm{~cm}^{2} / \mathrm{sec} の$ 機械油を用いた。油は温度に対する粘性の変化が大きい ので, 温度が $26^{\circ} \mathrm{C}, 45^{\circ} \mathrm{C}, 68.5^{\circ} \mathrm{C}$ のときの動粘性係数 をRedwood 粘度計によって測定し ${ }^{10)}$ ，規定のグラフ用 紙にプロットして, 温度と動粘性係数との関係直線をえ た。これを用いれば，実験時に温度を測定することによ り, 動粘性係数の值を知ることができる。次に自由地下 水面つ形状は, 内側のアクリル板の裏側に張りつけた方 眼紙を用いて読み取った。

\section{（2）解析結果と実験結果との比較}

まず自由地下水面について調べてみよう。 $r / H_{0}=0.4$ の比較的大きな暗きょ径の場合の計算結果と実験結果を 図一9 に示している。これを比較すると， $H_{A} / H_{0}$ が小 さいとき暗きょの近くで計算結果が実験結果より高い位 置を示している。これは図一6に示されるように, 解析 結果が暗きょ周壁の位置で, 実際のポテンシャルより大 きな值をもつためと考えられる。しかし，その相違はわ ずかであり，暗きょ径が大きいと解析誤差も大きいこ

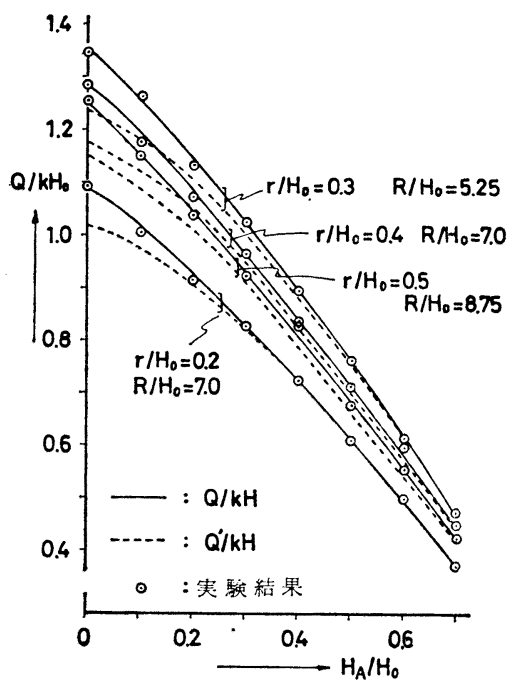

図一10 暗きょ取水量の実験結果との比較

と，および $H_{A} / H_{0}$ が大きくなるとよく一致することな どを考慮すれば，解析結果はほぼ満足できる解であるこ とがわかる。

次に暗きょ取水量について調べてみよう。実験は，rl $H_{0}=0.2,0.3,0.4$ および 0.5 の場合について行ない, 暗きょ内水圧を $H_{A} / H_{0}=0 \sim 0.7$ と変化させて, 流量を メスシリンダーで測定した。解析結果を実験結果と比較 すると，図一10 に示すように，よく一致している。

以上によって, 自由地下水面と暗きょ取水量の解析結 果が，実験結果とよく一致することが確かめられたもの と考える。なお図一10には参考までに， $Q^{\prime} \mid k H_{0}$ の值を 破線で示しているが，これより $r / H_{0}$ が小さい場合，あ るいは $H_{A} / H_{0}$ が大きい場合には， $Q^{\prime} / k H_{0}$ を暗きょ取 水量とみなしても，誤差は少ないことがわかる。

\section{5. 計算図表および境界条件と取水量との関係}

\section{（1）計算図表}

本解析結果から暗きょ取水量を求める際には, 式 (15) 〜 (22) の試行演算と式 (23) の数值積分が含まれて, かなり面倒である。そこで算定に便利なよらに, $Q / k H_{0}$ の計算図表を作成した。これを図一11 に示す。これよ $) ~ r / H_{0}=0.01 \sim 0.5, R / H_{0}=2 \sim$ $2500, H_{A} / H_{0}=-0.3 \sim 0.7$ の範 囲の暗きょ取水量を読み取ること ができる。眓中の点線は, 計算例 として $R / H_{0}=13.3, r / H_{0}=0.3$, $H_{A} / H_{0}=0.1$ のとき $Q / k H_{0}=0.86$ がえられる手順を例示したもので 


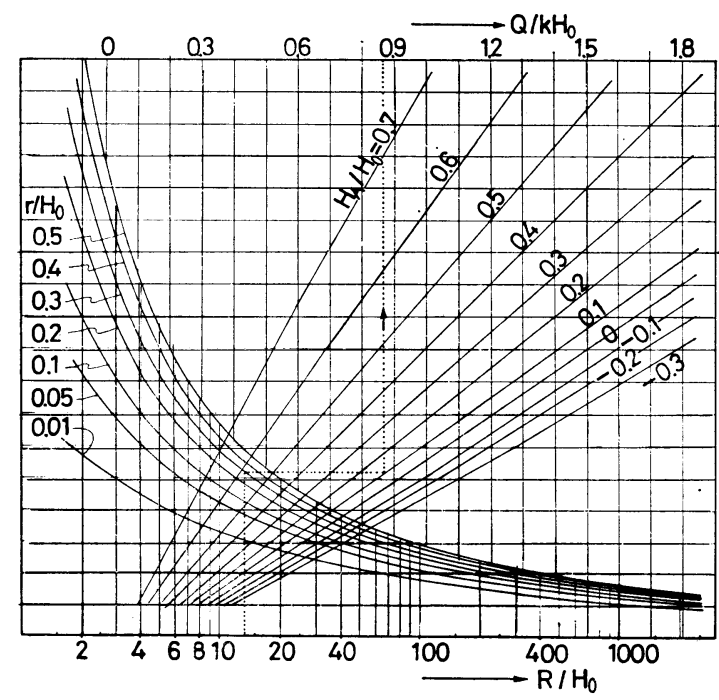

図一11 暗きょ取水量の計算図表

ある。

\section{（2）境界条件よ取水量との関係}

以上の解析結果を用いて, 境界条件の変化にともなう 暗きょ取水量の変化を調べてみよう。まず図一10は Q/ $k H_{0} \sim H_{A} / H_{0}$ の関倸を示したものであり，これより， 暗きょ内水圧を低くするほど取水量が多くなり，その変 化はほぼ直線的であることがわかる。次に図一11 の繸 軸は, 取水量を求める際の混乱をさけるために記入して ないが, $H_{A} / H_{0}=0.4$ のときの $Q / k H_{0}$ であり, 図中の 右下がりの曲線群は $Q / k H_{0} \sim R / H_{0}$ の関係を示したもの である。ここに影響範囲の值 $R$ は, 井戸の影響半径と 同様に, 取水施設の設計時には, その地盤に適した值を 与えて取水量を予測する ことになるが，この図よ り，影響範囲がある程度 大きいとき，あるいは暗 きょ径が小さいときに は, 取水量に与える影響 範囲の影響は小さいこと がわかる。図一12 は Q/ $k H_{0} \sim r / H_{0}$ の関係を示 したもので，暗きょ径が 大きいほど取水量が多 く, 暗きょ径の違いによ る取水量の変化は, 暗き よ径が小さいときに大き いことがわかる。図一13 はもとの地下水面と暗き ょ内水圧との水頭差を $\Delta H$ とし，暗きょの埋

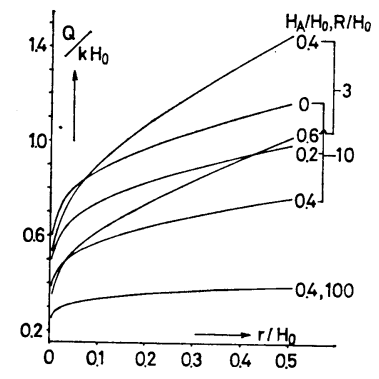

図一12 算定結果

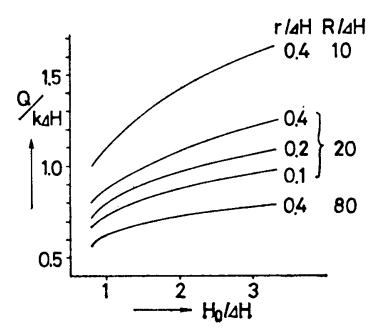

図-13 算 定 結 果

設哚さを変えた場合の取水量の変化を示したものであ る。これより水頭差が一定であれば，暗きょを深く埋設 するほど取水量は多くなり, その増加率は深くするほど わずかながら小さくなることがわかる。また影響範囲が 小さいとき，あるいは暗きょ径が大きい場合に増加率が 大きいようである。

次に自由地下水面の高さを調べてみよう。まず図一9 より，暗きょ内水圧を低くするほど自由地下水面の位置 が近くなることがわかる。次に暗きょ内が満水状態のと きの最低点の高さについて求めた 図一14 より，暗きょ 径が大きいほど地下水面が低いこと，および影響範囲が ある程度大きくなると, 最低点の高さに与える影響範囲 の影響は小さくなることなどがわかる。

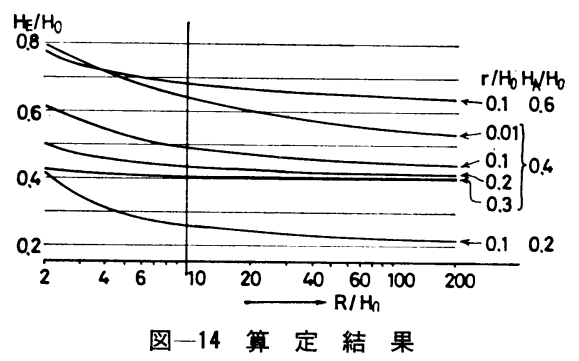

\section{6. 暗きょが多数並列された場合}

半無限浸透領域の同じ深さの位置に, 同じ規模の円形 暗きょを一定間隔で多数並列させて取水する場合の, 暗 きょ取水量と自由地下水面の形状を検討してみょう。

\section{（1） 複素ポテンシャル}

図一15の流れの状態を調べてみると，各暗きょ間の 中央線 $\mathrm{FD}$ および暗きょ中心軸 $\mathrm{ED}$ に関して左右対称 である。したがって解析領域は八ッチの部分を考える。 式 (2) より領域境界上の $\theta$ の值を求めると, 図一16 のような $\theta$ 平面がかける。これを図一17 の半平面に写 像するとき, $\mathrm{D}$ 点を無限遠点に, $\mathrm{E}$ 点を $t=0$ に, $\mathrm{F}$ 点

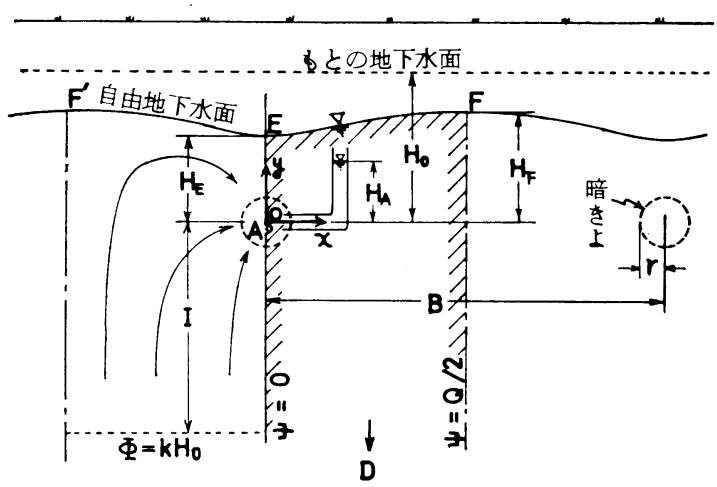

図一15 暗きょが多数並列された場合の $z$ 平面 


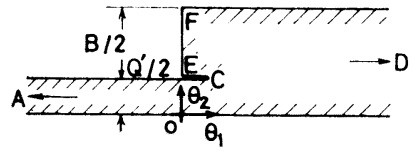

図 $16 \theta$ 平 面

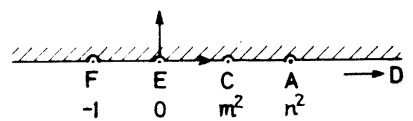

図 $17 t$ 平 面

を $\iota=-1 に$ 選び，C点㧍よびA 点の位置を $t=m^{2} お よ$ び $=n^{2}$ よする, Schwarz-Christoffel の変換式より

$$
\Theta=M \int \frac{1-m^{2}}{\sqrt{ } t+1 \cdot \sqrt{t}\left(t-n^{2}\right)} d t
$$

ここにMは倸数である。

ここで

$$
t=-\sin ^{2} \zeta
$$

上打く上，式（26）は次式のよ5に積分される。

$$
\Theta=2 i . M\left\{5-\tan ^{-1}\left(\sqrt{ } n^{2}+1 \cdot \tan \zeta / n\right) / G\right\}+C_{1}
$$

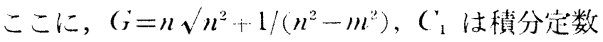
また式（27）の変換によ，

て, 図一17の半平泊は図 -18の带状領域に写像さ れる。この図一18の流入 点へのポテンシャル流は, 带状領域に流入点が 2 つあ る場合のポテンジャル流と 同じであり，複素ポテンシ ヤルの式は，1つの流人点 への流人星孝 $\left(マ^{\prime}\right.$ とすると 次式で表わさ机る。

$$
W=\left(Q^{\prime} / 2 \pi\right) \text {. }
$$

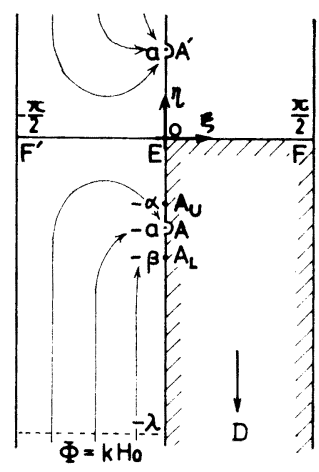

図 18 万平面

$$
\ln \{\sin (\zeta+i a) \cdot \sin (\zeta-i a)\}+\mu
$$

ここに式（27）より $a=\sinh ^{-1} n$

\section{(2) $\Phi$ およひ $\psi$ の式}

式 (28)に $\zeta=\xi+i \eta$ を代入して実数部と虚数部にわ け, 領域内での逆正接の值を, $\mathrm{AD}$ および DF 区間で, $\tan ^{-1} 0=0$, EA 区間で $\tan ^{-1} 0=\pi$ と選攵と, $C_{1}=0$ お よび $M=G \cdot Q^{\prime} / 2 \pi$ がえられる。これらを式 (28) の実 数部と虚数部に代人して整理すると, 次式がえられる。

$$
q-k y=-\frac{Q^{\prime}}{4 \pi} \cdot \ln \frac{X^{2}+(1+Y)^{2}}{X^{2}+(1-Y)^{2}}-\frac{Q^{\prime}}{\pi} G \eta
$$

$$
\psi^{\prime}+k x=\frac{Q^{\prime}}{2 \pi} \cdot \tan ^{-1} \frac{2 X}{X^{2}+Y^{2}-1}+\frac{Q^{\prime}}{\pi} G \xi
$$

\section{ここに}

$$
\begin{aligned}
& X=\frac{\sqrt{n^{2}+1}}{n} \frac{\sin 2 \xi}{\cos 2 \xi+\cosh 2 \eta} \\
& Y=\frac{\sqrt{n^{2}+1}}{n} \frac{\sinh 2 \eta}{\cos 2 \xi+\sinh 2 \eta}
\end{aligned}
$$

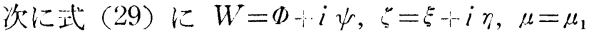
$+i \mu_{2}$ を代入して実数部上虚数部にわけ，E点よ り求めた

$$
\mu_{1}=k H_{E}-\left(Q^{\prime} / 4 \pi\right) \cdot \ln n^{4}
$$

および F点より求めた $\mu_{2}=Q^{\prime} / 2$ を代入して整理 寸ると，

$$
\begin{aligned}
\mathcal{D}= & \left(Q^{\prime} / 4 \pi\right) \cdot \ln \left[\left\{\sin ^{2} \xi+\sinh ^{2}(\eta+a)\right\}\right. \\
& \left.\cdot\left\{\sin ^{2} \xi+\sinh ^{2}(\eta-a)\right\} / n^{4}\right]+k H_{E} \cdots \cdots(32) \\
\psi= & \left(Q^{\prime} / 2 \pi\right) \cdot\left\{\tan ^{-1}\{\cot \xi \cdot \tanh (\eta+a)\}\right. \\
& \left.+\tan ^{-1}\{\cot \xi \cdot \tanh (\eta-a)\}+\pi\right] \cdots \cdots \cdots(33)
\end{aligned}
$$

がえられる。

\section{（3）暗きょ取水量 $\boldsymbol{Q}$}

まず式 (30)，(31)，(32)，(33）に各点の境界条件を 与之て, 流入点八の流入量 $Q^{\prime}$ の算定式を求めてみよ う。

暗き上の中心軸上で, 速度ポテンシャルが, もとの地 下水面と同じポテンシャル $\Phi=k H_{0}$ に回復する位置を $y=-I, \eta=-\lambda$ とすると, $\xi=0, X=0, Y=-\tanh \lambda$. $\sqrt{n^{2}+1 / n}$ であるから，式 (30)，(32)より

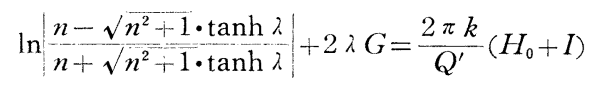

$$
\ln \left\{\sinh (\lambda-a) \cdot \sinh (\lambda+a) / n^{2}\right\}
$$$$
=\left(2 \pi k / Q^{\prime}\right) \cdot\left(H_{0}-H_{F}\right)
$$

自由地下水面は暗きょ間の中央 ( $\mathrm{F}$ 点) で最も高くな

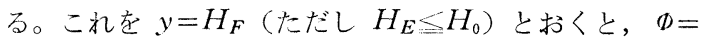
$k H_{F}, \quad \gamma=Q^{\prime} / 2, x=B / 2, \xi=\pi / 2, \quad \eta=0, \quad X=\infty, \quad Y=0$ であるから，式 (31)，(32)より

$$
\begin{aligned}
& G \equiv n \sqrt{n^{2}+1} /\left(n^{2}-m^{2}\right)=k B / Q^{\prime}+1 \\
& \left(2 \pi k / Q^{\prime}\right)\left(H_{F}-H_{E}\right)=\ln \left(1 / n^{2}+1\right)
\end{aligned}
$$

暗きょ周壁の下端 $\mathrm{A}_{\mathrm{L}}$ 点では, $\eta=-\beta(\beta>1)$ とお くと, $\Phi=k H_{A}, \quad y=-r, \quad \xi=0, \quad X=0, \quad Y=-\tanh \beta \cdot$ $\sqrt{n^{2}+1} / n$ であるから，式 (30)，(32)より

$$
2 G \beta+\ln \left|\frac{n-\sqrt{ } n^{2}+1 \cdot \tanh \beta}{n-\sqrt{ } n^{2}+1 \cdot \tanh \beta}\right|=\frac{2 \pi k}{Q^{\prime}}\left(H_{A}+r\right)
$$

$$
H_{E}=H_{A}-\left(Q^{\prime} / 2 \pi k\right) \cdot \ln \{\sinh (\beta-a)
$$$$
\left.\cdot \sinh (\beta+a) / n^{2}\right\}
$$

$\mathrm{A}_{\mathrm{U}}$ 点の位置は, 暗きょ内が満水状態の場合には暗き ょ周壁の上端とし, 未満水状態の場合には暗きょ周壁と 自由地下水面との交点とする。

暗きょ内が満水状態の場合には, $\eta=-\alpha(\alpha<1)$ とおく と, $\Phi=k H_{A}, y=r, \xi=0, X=0, Y=-\tanh \alpha \cdot \sqrt{n^{2}+1 / n}$ であるから，式 (30)より

$$
2 G \alpha+\ln \left|\frac{n-\sqrt{n^{2}+1} \cdot \tanh \alpha}{n+\sqrt{n^{2}+1} \cdot \tanh \alpha}\right|=\frac{2 \pi k}{Q^{\prime}}\left(H_{A}-r\right)
$$


式 (32) より

$$
\begin{aligned}
H_{E}= & H_{A}-\left(Q^{\prime} / 2 \pi k\right) \\
& \cdot \ln \left\{\sinh (a-\alpha) \cdot \sinh (\alpha+a) n^{2}\right\}
\end{aligned}
$$

となるから, 式 (39) と連立させれば

$$
2 n^{2}=\sinh ^{2} \alpha+\sinh ^{2} \beta
$$

がえられる。したがって暗きょ内が満水状態の場合の， 流入点への流入量 $Q^{\prime}$ と自由地下水面の高さ $H_{E}$ およ び $H_{F}$ は，与えられた境界 $r, H_{A}, B, H_{0}, I$ について 式 (34)，(35)，(36)，(37)，(38)，(39)，(40)，(41) を連立させて解いてえられる。また $r, H_{A}, B, H_{F}$ を 与えて $Q^{\prime}$ と $H_{E}$ を求めることもでき, この場合には 式 (36)，(37)，(38)，(39)，(40)，(41) を連立させて 解くことになる。

次に暗きょ内が未満水状態の場合の $\mathrm{A}_{\mathrm{U}}$ 点では, $\xi=$ $\alpha(\alpha \geqq 0), y=y_{A}$ とおくと, $\Phi=k y_{A}, \psi=Q^{\prime} / 2, x=$ $\sqrt{r^{2}-y_{A}}, \eta=0, X=\tan \alpha \cdot \sqrt{n^{2}+1} / n, \quad y=0$ であるか ら, 式 (31), (32) より

$$
\begin{aligned}
& 2 G \alpha+\tan ^{-1} \frac{2 n \sqrt{n^{2}+1} \cdot \tan \alpha}{\left(n^{2}+1\right) \cdot \tan ^{2} \alpha-n^{2}} \\
& =\frac{2 \pi k}{Q^{\prime}} \sqrt{r^{2}-y_{A}{ }^{2}}+\pi \\
& y_{A}=H_{E}+\left(Q^{\prime} / 2 \pi k\right) \cdot \ln \left(1+\sin ^{2} \alpha / n^{2}\right) \cdots .
\end{aligned}
$$

がえられる。したがって暗きょ内が未満水状態の場合の 流入点への流入量 $Q^{\prime}$ と自由地下水面の高さは, 暗きょ が 1 個の場合と同様に $m=0$ あるいは $y_{A}=H_{A}$ とおい て式 (34)，(35)，(36)，(37)，(38)，(39)，(42), (43) を連立させて解くとえられる。

以上の解析によって求められた流入点一の流れの各流 線上において，暗きょ周壁の位置で，与えられた暗きょ 周壁の速度ポテンシャルと一致するように補正したとき の流入量を, 式 (23) より求め, これを暗きょ取水量 $Q$ と考える。

\section{（4）自由地下水面と流線網}

自由地下水面は $\eta=0$ の直線に写像されているから， 式 (30)，(31)，(32) 上り

$$
\begin{array}{r}
x=\frac{Q^{\prime}}{2 \pi k} \cdot\left\{2 G \xi+\tan ^{-1} \frac{2 n \sqrt{n^{2}+1} \cdot \tan \xi}{\left(n^{2}+1\right) \cdot \tan ^{2} \xi-m^{2}}-\pi\right\} \\
\ldots \ldots \ldots \ldots \ldots \ldots \ldots \ldots \ldots \ldots \ldots(44) \\
y=\frac{Q^{\prime}}{2 \pi k} \cdot \ln \left\{(\sin \xi / n)^{2}+1\right\}+H_{E} \cdots \cdots \cdots \cdots(45)
\end{array}
$$

がえられる。したがって流入量の算定式よりえられる $Q^{\prime}, H_{E}, n, m$ の值を両式に代入すれば， $\xi$ を媒介変数 として自由地下水面を描くことができる。また領域内部 のゆ抢よび乡の值も, 式 (30)，(31)，(32)，(33) より $\xi \eta \eta$ を媒介変数として求めることができるから， これより流線網を描くことができる。図一19 は $H_{A} / H_{0}$ $=0.2, r / H_{0}=0.1, B / H_{0}=1.0, I / H_{0}=1.59$ の埸合の流
線網を示したものである。

7. Hele-Shaw モデル 実験による検証

図一8の実験装置を用いて 実験を行ない，暗きょ取水量 と自由地下水面の解析結果を 検討してみよう。モデルの浸 透領域の大きさ注，暗きょ間 隔を $B=30 \mathrm{~cm}$ とし, $\Phi=k H_{0}$

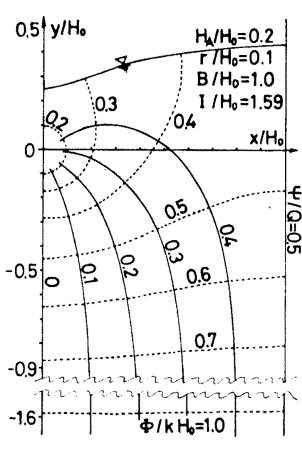

図-19 流 線 網 の等ポテンシャル線は，図一19 を参考にして， $x$ 軸と 平行な直線で近似し， $I=35 \mathrm{~cm}$ とした。

まず自由地下水面について調べてみよう。 $r / H_{0}=0.4$ の比較的大きな暗きょ径の場合の算定結果と実験結果を 図一20 に示している。これを比較すると， $H_{A} / H_{0}=0$ の場合に解析結果が実験結果よりやや高い位置を示す が，その相違はわずかであり，全体的にはよく一致して いるといえよう。

次に暗きょ取水量について, 解析結果と実験結果を比 較すると図一21 のようになり，暗きょ内が末満水状態 のとき, 解析結果が実験結果より大きな值を示す。しか し，その相違はわずかであるから，解析結果と実験結果 はほぼ一致しているといえよう。

以上のように, 解析結果と実験結果がほぼ一致するこ
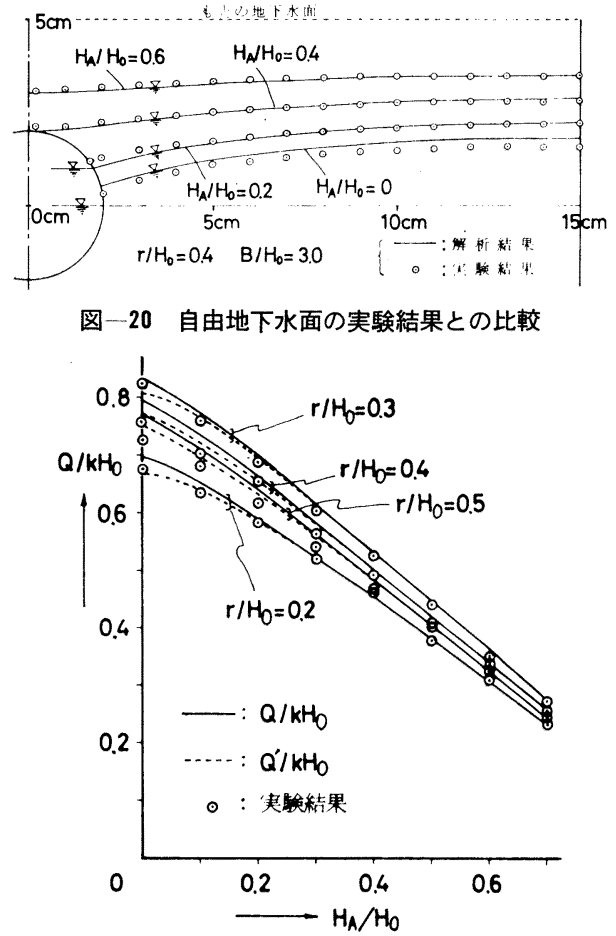

図一21暗きょ取水量の実験結果との比較 
とから，本解析絬果はほぼ满足できる解であると考える ことができる。

\section{8. 計算図表および境界条件と取水量との関係}

\section{(1) 計算図表}

境界条件として $H_{A}, r, B$ が与えられていて， $H_{F}$ を 知って $Q$ を求める場合, あるいは $Q$ を知って $H_{F}$ を 求める場合の部算図表を作成した。これを 図一22 に示

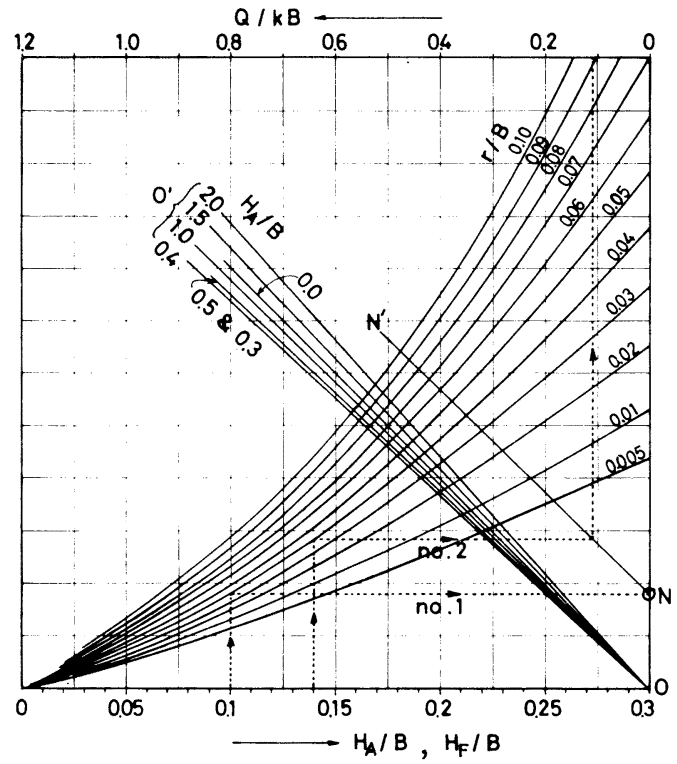

図 22 暗きょ取水量の計算図表

している。いまたとえば, $B=15 \mathrm{~m}, H_{0}=2.5 \mathrm{~m}, r=0.6$ $\mathrm{m}, H_{A}=1.5 \mathrm{~m}$ とし， $H_{F}=2.1 \mathrm{~m}$ であるあるときの 暗きょ取水量を求めてみよう。まず $H_{A} / B=0.1, r / B=$ 0.04 であるから, No. 1 の点線のように結んで, 点 $\mathrm{N}$ を 決める。この点 $\mathrm{N}$ を通り $\mathrm{OO}^{\prime}$ 線群の $H_{A} / B=0.1$ の直 線と平行な直線 $\mathrm{NN}^{\prime}$ を描き, $H_{F} / B=0.14$ から No. 2 の上うに引いた点線と $\mathrm{NN}^{\prime}$ 線との交点の横軸の值を読 み取れば $Q / k B=0.11$ をうる。また No. 2 の操作を逆 に行なえば, $Q / k B=0.11$ のときの $H_{F} / B=0.14$ を求 めることができる。

\section{（2）境界条件と取水量との関係}

暗きょ径や暗きょ内水压などが暗きょ取水量および地 下水酘の最低点の㽞さなどに与える影響は，傾问的には 図一10１4 と阔じ結果がえられる。したがってここで は，暗き上酒隔が暗きょ取水舅抒よび暗きょ間中央の地 下水泊门高さなどに与える影響について調へてみよう。

まず $Q / k H_{0} \sim B / H_{0}$ を求めると図一23 0 上うにな る。これより暗きょ阊隔を大きくすると取水翼は多くな

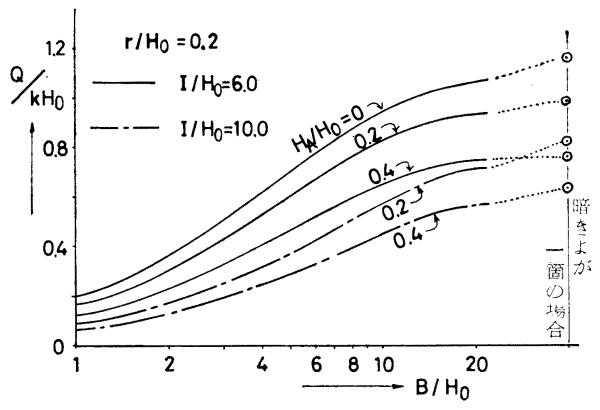

図一23 算 定 結 果

り，その増加率は 暗きょ間隔が小さ いときに大きいこ とがわかる。なお 参考までに，暗き 上が 1 個埋設され た場合の取水量を $R / H_{0}=I / H_{0}$ とお いて求め, 図中に 丸印で示してい る。次に $H_{F} / H_{0}$ $\sim H_{A} / H_{0}$ を求为 ると図一24のように なる。こ礼より暗きょ 間中央の地下水面の高 さは, 暗きょ内水圧を 低くするほど低くな り，その変化は暗きょ 間隔が小さいときに大 きいことがわかる。次 に，もとの地下水面と 暗きょ内水圧との水頭 差 $\Delta H$ を変えずに,

暗きょの埋設深さを変 えた場合の $H_{0} / \Delta H \sim$ $Q / k \Delta H$ および $\left(H_{F}\right.$ $\left.-H_{A}\right) / \Delta H$ の関係を, $r / \Delta H=0.25, B / \Delta H=$ 7.5 の壦合汇ついて求 めると, 図一25のよ らになる。これより暗 きょ閵中央の地下水面 の高さは $H_{0} / \Delta H=1$ 〜2の場合には暗きょ の位置を哚くするほど 低くなるが，暗きょの 媣さが水頭差に比べて

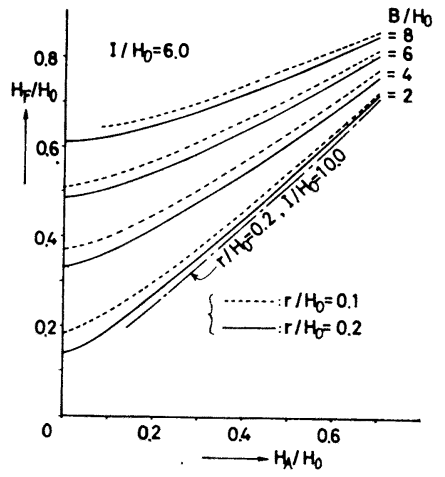

図一24 算 定結 果

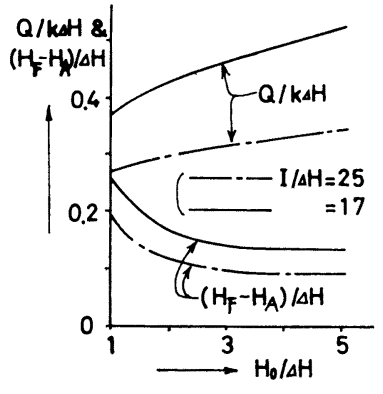

図一25 算 定 結 果

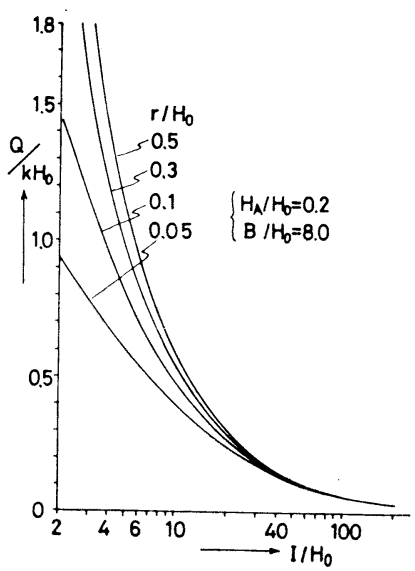

図-26 算 定 結 果 
大きくなると，ほとんど変化しなくなること，また暗き 上取水量は暗きょの位置を深くするほど多くなることな どがわかる。なお $I / H_{0}$ が取水量に与える影響は，図一 26 に示すように, 図一11の $R / H_{0}$ が取水量に与える 影響に比べて大きい。またこの影響は暗きょ径が大きい ほど大きいようである。

\section{9.むすび}

以上によって, 自由地下水面をもつ均一な透水性の半 無限浸透領域に, 円形の集水暗きょが 1 個, あるいは同 じ深さに並列して多数埋設された場合の暗きょへの浸透 流について, 暗きょ内が満水状態と末満水状態での解を 求め，これより，任意の暗きょ内水仕における円形暗き ょの取水量と自由地ト水泊の形状などを求めることがで きたものと考える。この取水量の算定には数值微分上数 值積分が含まれるので，咕算仪表を用意した。これを特 いれば簡単に暗きょ取水量を求めることができるである 5 。

以上の解析結果から, 暗きょを深く埋設するほど, 暗 きょ内水圧を下げるほど，および暗きょ径を大きくする ほど暗きょ取水量は多くなり, 自由地下水面の高さは低 くなることがわかった。また暗きょ間隔を大きくする と, 暗きょ取水量は多くなるが，暗きょ間中央の地下水 面の高さが高くなることなどが明らかになった。

本解析結果は暗さょ排水に㧍ける, 暗きょ排水最や自 由地下水面の低下にも利用できるものである。

また本論文では上部境界を自由地下水面として検討し たが，本論文の解析を若干修正することにより，淡塩 2 層地盤において円形暗きょで塩水を排水する場合の, 淡 塩境界面について検討することができる ${ }^{11)}$ 。

終わりに, 本研究を進めるにあたり, 終始貴重なご指
導をいただいた九州大学: 上田年比古教授に深く感謝い たします。また実験装置の作成および実験にご協力いた だいた本学職員木村繁之氏に感謝する。なお上記の計算 には本学大型計算機センターの FACOM 230-60) を使用 した。また本研究は文部省科学研究費の援助をうけた。

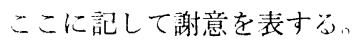

\section{参 考 文 献}

1）上田・杉尾：被压水で满たされれた形暏きょの取水量に ついて, 土木学会論文報售集, No. 194, p. 91 101, 1971.

2）上田・杉尾：水で満たされていない円形暗きょの取水量 について, 土木学会論文報告集, No. 201, p. 77〜86, 1972.

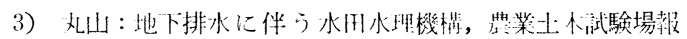

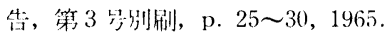

4) Schilfgaarde, J.V., Kirkham, I). and Frevert, R.F. : Physical and Mathematical Theoris of Tile and Ditch Drainage and their Usefulness in Design, Research Bulletin, Iowa, Agr. Exp. Stat. AMES, 136, p. 667 $\sim 706,1956$.

5) Polubarinova-Kochina : Theory of Ground Water Movement, Princeton Univ. Press, p. 120, 1962.

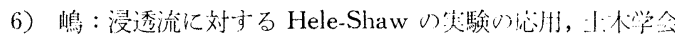
就 36 卷 5 号, p. $21 \sim 24,1951$.

7) Hall, H.P. : An Investigation of Steady Flow toward a Gravity Well, La Hauille Blanche, Vol. 10, p. 8 $35,1955$.

8) Guitjens, J.C. and Luthin, J.N.: Viscous Model Study of Drain Spacing on Sloping Land and Comparison with Mathematical Solution, Water Resources Research, Vol. 1, No. 4, p. 523 530, 1965.

9) Columbus, N. : Viscous Model Study of Sea Water Intrusion in Water Table Aquifers, Water Resources Research, Vol. 1, No. 2, p. 313 323, 1965.

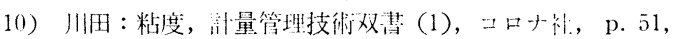
1969.

11）上田・杉尾：淡程 2 層地盤内の海水取水円形隐きょに上

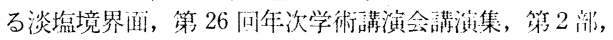
p. $469 \sim 472,1971$.

(1972. 7.20 . 受付) 